\title{
Children of male spray painters: weight and length at birth
}

\author{
Gunnar V Höglund, E Lennart Iselius, Bengt G Knave
}

\begin{abstract}
The course and outcome of the pregnancies of the wives of 80 spray painters and 80 electronics workers were recorded from birth registers, hospital records, and a questionnaire. The two groups of men had previously been subjected to psychological, psychiatric, neurophysiological, and neurological tests. The variables recorded were occupational exposure to solvents; number of births, ectopic pregnancies, and miscarriages; weight, length, and malformations of the newborn children; duration of the pregnancies; birth complications; and neonatal hospital treatment. The mean length and weight of the children of spray painters at birth were slightly lower than those of the children of electronics workers. No differences were recorded for serious complications of pregnancy, malformations, or clinical course after birth.
\end{abstract}

Occupational exposure of women to organic solvents may be associated with an increased incidence of chromosomal aberrations, spontaneous abortions, and congenital malformations..$^{1-5}$ Less well documented is the question as to whether exposure of the father might affect the course of pregnancy and development of the fetus. Abnormal pregnancies after paternal exposure to toxic substances have been reported, ${ }^{67}$ and exposure of the father to organic solvents may also affect the development of the child. Reported effects include infertility of the exposed men, ${ }^{8}$ as well as malformations ${ }^{910}$ and brain tumours ${ }^{11}$ in their children. One register based study 1213 indicated that occupational exposure of men to solvents is associated with a slight reduction in weight and length of the newborn children. An investigation by Daniell and Vaughan, ${ }^{14}$ based on birth certificates, suggested an increased incidence of

Department of Neuromedicine, National Institute of Occupational Health, S-171 84 Solna, Sweden G V Höglund, B G Knave

Department of Clinical Genetics, Karolinska Hospital, S-104 01 Stockholm, Sweden

E L Iselius low birth weight, and in a subsequently published case-referent study Taskinen et $a l^{15}$ found that paternal exposure to organic solvents increases the odds ratio for spontaneous abortions. In their report, Daniell and Vaughan ${ }^{14}$ state that other studies of possible effects of paternal exposure to organic solvents on the offspring are needed.

The present study concerns the outcome of pregnancies when the father has been occupationally exposed to organic solvents before conception.

\section{Material and methods}

Data on the newborn children of 80 male spray painters and 80 male workers in electronics plants were compared. Elofsson $e t$ al ${ }^{16}$ examined the function of the nervous system of workers (reference group 2 in their study) with psychiatric, psychometric, neurological, neurophysiological, ophthalmological, and neuroradiological tests. The painters and electronics industry workers were stratified into five age groups-namely, below 25, 26-35, 36-45, 46-55, and 56-65 years. Each age group of painters comprised eight car painters and eight industrial painters. All of the painters had been exposed to several solvents at concentrations below the threshold limit values in Sweden. For details of workers and their exposures see Elofsson et al. ${ }^{16}$

\section{EXPOSURE OF THE MEN AND WOMEN BEFORE}

CONCEPTION

The duration of the occupational exposure of the men to solvents, including the duration of exposure free periods before conception, was calculated from the exposure data recorded by Elofsson $e t$ al. ${ }^{16}$ The corresponding data on occupational and other exposure to solvents, or to radiation, of the wives of these men were obtained from a questionnaire answered by the man together with his wife. (In the present article wife refers either to the woman married to the spray painter or electronics worker, or to another woman together with whom the spray painter or electronics worker had a child or pregnancy.) The questionnaire was answered by 73 spray painters $(91 \%)$ and 68 electronics workers $(85 \%)$. Three electronics workers had died since the completion of the study by Elofsson et al. ${ }^{16} \mathrm{~A}$ fourth 
electronics worker who did not answer the questionnaire had no children.

\section{OTHER DATA ON THE MEN AND WOMEN}

Alcohol consumption and smoking were recorded in the questionnaire. The men were divided into two groups according to alcohol consumption $(<8 \mathrm{~g}$ a day, $\geqslant 8 \mathrm{~g}$ a day), and three groups according to smoking ( $<5$ cigarettes a day, $\geqslant 5-15$ cigarettes a day, $\geqslant 15$ cigarettes a day). The women were divided into two groups according to alcohol consumption and smoking (alcohol $<1 \mathrm{~g}$ a day, $\geqslant 1 \mathrm{~g}$ a day; smoking 0 cigarettes a day, $>0$ cigarettes a day). The alcohol consumption and smoking for the wives of the spray painters were compared with those of the wives of the electronics workers during the three months preceding their pregnancies, the first three months of the pregnancies, and the remaining part of the pregnancies. Data were missing on 13 spray painters and 10 electronics workers, and on 18 wives of spray painters and 12 wives of electronics workers. A stratified analysis of the data did not support the hypothesis that a difference in consumption of alcohol or smoking between the groups of men or women could explain the differences found in weight or length of the newborn children or in duration of the pregnancies.

The alcohol consumption of the men was also investigated by Elofsson et $a l^{16}$ who found no difference in consumption between the spray painters and the electronics workers. The age of the men and women at the birth of their children, and the weight and body height of the men and women at the time they answered the questionnaire were recorded. The age of the women was also obtained from the hospital records. The mean ages of the spray painters and their wives at the time of birth of all of their children, or of the wife's first child, were not different from those of the electronics workers and their wives; nor was there any difference in body height of the men at the time of birth of all their children, or of the wife's first child. The response rate was too low to allow a statistical treatment of the body height of the wives or the weight of the men and their wives.
PREGNANCIES, BIRTHS, AND CHILDREN

All children of the spray painters and electronics workers were identified from the questionnaires and official birth registers. Data on the course and outcome of the pregnancies were obtained from obstetric and hospital records. (Almost all children in Sweden are born in hospitals or other obstetric units.) These data included information on miscarriages, ectopic pregnancies, legal abortions, the course of delivery, congenital malformations, and neonatal treatment of the newborn child. Weight, length, and sex of the newborn child, and the duration of the pregnancy, were obtained from the same records. Table 1 shows the total number of children and fetal losses recorded. Pregnancies that occurred before the first occupational exposure of the spray painters to organic solvents have been excluded from all tables. Parametric and non-parametric (Mann-Whitney) tests were used for the statistical analysis. The response rates in the questionnaire section on the use of contraceptives and difficulty of conception were insufficient to justify a statistical analysis.

\section{Results}

The obstetric and hospital records showed no differences between the spray painters and electronics workers for frequency of miscarriages, ectopic pregnancies, sex ratio among the children, birth complications, and neonatal hospital treatment. Only one malformation (father not exposed) was recorded.

Table 2 shows the mean weight and length of the children at birth and the mean duration of the pregnancies. The mean length of the children of the spray painters was slightly less than that of the children of the electronics workers. The difference was: all children $0.008 \mathrm{~m}(\mathrm{p}=0.02)$; boys $0.013 \mathrm{~m}$ $(p=0.01)$; girls $0.006 \mathrm{~m}(\mathrm{p}>0.05)$. The mean weight of the children of the spray painters tended to be lower. The difference was: all children $90 \mathrm{~g}$, boys $150 \mathrm{~g}$, girls $48 \mathrm{~g}(\mathrm{p}>0.05)$. The mean duration of the pregnancies showed a tendency to be slightly shorter. The difference was: all children 1.5 days, boys 2.0 days, girls 0.9 days $(p>0.05)$. No relation was seen

Table 1 Number of fathers, mothers, births, and fetal losses

\begin{tabular}{|c|c|c|c|c|c|c|}
\hline & \multicolumn{4}{|l|}{ Births } & \multicolumn{2}{|c|}{ Fetal losses } \\
\hline & Fathers & Mothers & Sons & Daughters & Women & Fetuses \\
\hline $\begin{array}{l}\text { Spray } \\
\text { Electr } \\
\text { All }\end{array}$ & $\begin{array}{r}51 \\
51 \\
102\end{array}$ & $\begin{array}{r}54 \\
53 \\
107\end{array}$ & $\begin{array}{r}55 \\
51 \\
106\end{array}$ & $\begin{array}{l}37 \\
49 \\
86\end{array}$ & $\begin{array}{r}13 \\
8 \\
21\end{array}$ & $\begin{array}{l}14 \\
12 \\
26\end{array}$ \\
\hline
\end{tabular}

«Father exposed three months before to one month after the calculated time of conception.

Children born $(n=17)$ and fetal losses $(n=2)$ occurring before the spray painters' $(n=14)$ first exposure to organic solvents are excluded. Spray $=$ Male car or industrial spray painters $(n=80)$ occupationally exposed to organic solvents. Electr $=$ Male workers in electronics industry $(n=80)$ not occupationally exposed to organic solvents. 
Table 2 Mean duration of pregnancy, and mean weight and length of newborn children of fathers exposed (spray painters) or not exposed (electronics workers) to organic solvents

\begin{tabular}{|c|c|c|c|c|c|c|c|}
\hline \multirow[b]{2}{*}{ Fathers } & \multirow{2}{*}{$\begin{array}{l}\text { Mothers } \\
\text { No }\end{array}$} & \multicolumn{2}{|l|}{ Weight } & \multicolumn{2}{|l|}{ Length } & \multicolumn{2}{|c|}{ Duration of pregnancy } \\
\hline & & $g(S D)$ & No & $m(S D)$ & No & Days ( $S D$ ) & No \\
\hline \multicolumn{8}{|c|}{ All children } \\
\hline $\begin{array}{l}\text { Exposed }(n=51) \\
\text { Not exposed }(n=51) \\
\text { p Value (Mann-Whitney) }\end{array}$ & $\begin{array}{l}54 \\
53\end{array}$ & $\begin{array}{c}3478(610) \\
3568(475) \\
0.39\end{array}$ & $\begin{array}{r}92 \\
100\end{array}$ & $\begin{array}{c}0.503(0.025) \\
0.511(0.021) \\
0.02\end{array}$ & $\begin{array}{l}89 \\
99\end{array}$ & $\begin{array}{c}-0.9(16.2) \\
+0.6(11.3) \\
0.73\end{array}$ & $\begin{array}{l}92 \\
99\end{array}$ \\
\hline \multicolumn{8}{|c|}{ First child } \\
\hline $\begin{array}{l}\text { Exposed }(n=33) \\
\text { Not exposed }(n=38) \\
\text { p Value (Mann-Whitney) }\end{array}$ & $\begin{array}{l}36 \\
39\end{array}$ & $\begin{array}{c}3255(692) \\
3562(453) \\
0.04\end{array}$ & $\begin{array}{l}36 \\
39\end{array}$ & $\begin{array}{c}0.494(0.030) \\
0.512(0.023) \\
0.02\end{array}$ & $\begin{array}{l}35 \\
39\end{array}$ & $\begin{array}{c}-5.4(21.3) \\
+0.7(9.5) \\
0.36\end{array}$ & $\begin{array}{l}36 \\
39\end{array}$ \\
\hline
\end{tabular}

*Deviation in days from calculated date of birth.

First child $=$ Mother's first child and first pregnancy.

between the duration of the father's exposure and the weight or length of the newborn child.

A comparison between the firstborn children in the two groups also showed differences. The firstborn child is here defined as the first child of the mother that was also her first pregnancy. Table 2 shows that the mean differences between the children of the spray painters and those of the electronics workers were for weight $307 \mathrm{~g}, \mathrm{p}=0.04$ (boys $280 \mathrm{~g}$, girls $320 \mathrm{~g}$; $\mathrm{p}>0.05$ ) and length $0.018 \mathrm{~m}, \mathrm{p}=0.02$ (boys $0.019 \mathrm{~m}$, girls $0.014 \mathrm{~m} ; \mathrm{p}>0.05)$. The mean duration of the first pregnancy tended to be shorter $(6 \cdot 1$ days; boys 3.3 days, girls 9.8 days; $p>0.05$ ). No differences in weight, length, or duration of pregnancy (mean values) were established for the second, third, and (in one group) fourth or later children of the spray painters compared with the corresponding children of the electronics workers, although the mean length was consistently shorter.

The mean length of the children of spray painters was also smaller, and their mean weight was also lower than those of the children of electronics workers if only near normal term infants were analysed. The differences were: all children at maturity $0 \pm 1$ days; weight $24 \mathrm{~g}$, length $0.0006 \mathrm{~m}$; $0 \pm 2$ days: weight $28 \mathrm{~g}$, length $0.0035 \mathrm{~m} ; 0 \pm 3$ days, weight $36 \mathrm{~g}$, length $0.0035 \mathrm{~m} ; 0 \pm 4$ days, weight $69 \mathrm{~g}$, length $0.0060 \mathrm{~m} ; 0 \pm 5$ days, weight $63 \mathrm{~g}$, length $0.0058 \mathrm{~m} ; 0 \pm 7$ days; weight $91 \mathrm{~g}$, length $0.0087 \mathrm{~m} ; 0 \pm 14$ days, weight $38 \mathrm{~g}$, length $0.062 \mathrm{~m}$. For the mother's first child the results were: at maturity $0 \pm 1$ days, weight $700 \mathrm{~g}$, length $0.0200 \mathrm{~m} ; 0 \pm 2$ days, weight $256 \mathrm{~g}$, length $0.0114 \mathrm{~m} ; 0 \pm 3$ days, weight $256 \mathrm{~g}$, length $0.0114 \mathrm{~m} ; 0 \pm 4$ days, weight $199 \mathrm{~g}$, length $0.0107 \mathrm{~m}, 0 \pm 5$ days: weight $225 \mathrm{~g}$, length $0.0112 \mathrm{~m} ; 0 \pm 7$ days, weight $318 \mathrm{~g}$, length $0.0183 \mathrm{~m} ; 0 \pm 14$ days, weight $210 \mathrm{~g}$, length $0.0125 \mathrm{~m} ; \geqslant 8$ days, weight $111 \mathrm{~g}$, length $0.0115 \mathrm{~m}$; $\leqslant 8$ days, weight $445 \mathrm{~g}$, length $0.0231 \mathrm{~m}$. All $\mathrm{p}$ values were $>0.05$.
An attempt was made to compare the mean weight and length of the children of spray painters with those of the electronics workers after correction for the tendency of the pregnancy of the spray painters' wives to be slightly shorter than that of the electricians' wives. A linear regression coefficient (expressing increase in weight or length per unit time) was calculated for both sets of children. The weight of all children was then recalculated to the expected weight if they had been born at exactly full term. The mean weight of the spray painters' children was still lower, and their mean length was smaller, after such correction. The differences were: all children, weight $66 \mathrm{~g}$ (p >0.05), length $0.0077 \mathrm{~m}$ ( $p<0.01$ ); weight of mother's first child $158 \mathrm{~g}$ (p > 0.05), length $0.0119 \mathrm{~m}(\mathrm{p}<0.05)$.

Six mothers were themselves occupationally exposed to organic solvents. As seen in table 3, the mean weight and length of their children and the mean duration of the pregnancies were slightly lower $(p \geqslant 0.05)$ than the corresponding data for the children of the non-exposed mothers. The mean and median weight and length of the children and the mean and median duration of the pregnancies were largest when none of the parents had been occupationally exposed to solvents, and the mean and median weight and length were smallest when both parents were exposed (table 4). Due to the small number of exposed mothers no statistical analysis of the differences was made.

\section{Discussion}

The present study concerns morphometric variables, primarily weight and length of the newborn children of spray painters and electronics workers. The same group of spray painters had previously ${ }^{16}$ been found to differ from the group of electronics workers in having more psychiatric symptoms, indicative of a slight cerebral lesion, and a larger incidence of impaired function within the peripheral and central 
Table 3 Duration of pregnancy and weight and length of newborn children of mothers occupationally exposed or not exposed to organic solvents

\begin{tabular}{|c|c|c|c|c|c|c|}
\hline \multirow[b]{3}{*}{ Mothers } & \multicolumn{6}{|l|}{ All children } \\
\hline & \multicolumn{2}{|l|}{ Weight } & \multicolumn{2}{|l|}{ Length } & \multicolumn{2}{|c|}{ Duration of pregnancy ${ }^{\star}$} \\
\hline & $g(S D)$ & No & $m(S D)$ & No & Days ( $S D$ ) & No \\
\hline $\begin{array}{l}\text { Exposed }(n=6) \\
\text { Not exposed }(n=85) \\
\text { p Value (Mann-Whitney) }\end{array}$ & $\begin{array}{c}3364(415) \\
3526(552) \\
0.31\end{array}$ & $\begin{array}{r}10 \\
152\end{array}$ & $\begin{array}{c}0.499(0.022) \\
0.507(0.024) \\
0.22\end{array}$ & $\begin{array}{r}10 \\
149\end{array}$ & $\begin{array}{c}-8 \cdot 0(14.7) \\
+0 \cdot 1(14.2) \\
0.05\end{array}$ & $\begin{array}{r}10 \\
151\end{array}$ \\
\hline
\end{tabular}

*Deviation in days from calculated date of birth.

Table 4 Duration of pregnancy and weight and length of newborn children of fathers and/or mothers occupationally exposed or not exposed to organic solvents

\begin{tabular}{|c|c|c|c|c|c|c|c|c|c|c|}
\hline \multirow[b]{3}{*}{$\begin{array}{l}\text { Fathers } \\
\text { Not }\end{array}$} & \multirow[b]{3}{*}{$\begin{array}{l}\text { Mothers } \\
\text { No† }\end{array}$} & \multicolumn{9}{|c|}{ All children } \\
\hline & & \multicolumn{3}{|c|}{ Weight } & \multicolumn{3}{|l|}{ Length } & \multicolumn{3}{|c|}{ Duration of pregnancy ${ }^{\star}$} \\
\hline & & $\begin{array}{l}\text { mean } \\
g\end{array}$ & $\underset{g}{\text { median }}$ & No & $\begin{array}{l}\text { mean } \\
m\end{array}$ & $\begin{array}{l}\text { median } \\
m\end{array}$ & No & $\begin{array}{l}\text { mean } \\
\text { Days }\end{array}$ & $\begin{array}{l}\text { median } \\
\text { Days }\end{array}$ & No \\
\hline $\begin{array}{l}-38 \\
-\quad 3 \\
+43 \\
+3 \\
\text { All }\end{array}$ & $\begin{array}{l}-40 \\
+\quad 3 \\
-45 \\
+\quad 3\end{array}$ & $\begin{array}{l}3571 \\
3537 \\
3483 \\
3105\end{array}$ & $\begin{array}{l}3575 \\
3658 \\
3470 \\
3135\end{array}$ & $\begin{array}{r}74 \\
6 \\
78 \\
4 \\
162\end{array}$ & $\begin{array}{l}0.511 \\
0.505 \\
0.504 \\
0.490\end{array}$ & $\begin{array}{l}0.510 \\
0.505 \\
0.500 \\
0.490\end{array}$ & $\begin{array}{r}73 \\
6 \\
76 \\
4 \\
159\end{array}$ & $\begin{array}{l}+1.6 \\
-13.0 \\
-\quad 1.3 \\
-\quad 0.5\end{array}$ & $\begin{array}{r}+2.0 \\
-7.0 \\
0.0 \\
-2.5\end{array}$ & $\begin{array}{r}73 \\
6 \\
78 \\
4 \\
161\end{array}$ \\
\hline
\end{tabular}

*Deviation in days from calculated date of birth.

$\dagger+=$ Exposed; $-=$ not exposed.

nervous systems as indicated by neurophysiological recordings. The mean weight and length of the first child of the painter's wife, if this child were her first pregnancy, and the mean length of all the painters' children, were slightly less than the corresponding data for the children of the electronics workers. No difference was established between the groups of painters and electronics workers, or the corresponding groups of mothers for age at the time of birth, body height of the father, alcohol consumption, or smoking.

A few mothers were themselves occupationally exposed to organic solvents. The mean weight and length of their children were slightly less ( $p$ values $>0.05$ ), and the mean duration of their pregnancies slightly shorter $(p=0.05)$, than the corresponding data for the children of the non-exposed mothers (table 3). This result is consistent with previous reports indicating that occupational exposure of women to organic solvents can affect their pregnancies. ${ }^{2-5}$

The results of the present study agree with those obtained in two register based studies. In one study, Mikkelsen ${ }^{12}$ and Mikkelsen et $a l^{13}$ concluded that children of painters have slightly lower weight and length at birth by comparison with children of electricians. This tendency was not associated with an increased rate of prematurity. In another study,
Daniell and Vaughan ${ }^{14}$ recorded data that suggested an increased incidence of low birth weight.

No difference between the children fathered by the painters and those fathered by the electricians in the incidence of malformations was recorded. An effect of the father's occupation on malformations would have had to be strong to manifest itself in a small sample like the present one. Such a strong effect, if it were present, is likely to have been detected previously by clinical observations.

The restriction of the difference (as shown by $p<0.05$ ), at least in weight, to the first child may be due to the fact that the number of first children was larger than the number of second children etc. It should be noted however, that the mean lengths of the second and later children were also slightly shorter $(p>0.05)$. A larger number of children would have allowed a closer statistical analysis of the morphometric variables in all groups.

The differences seen in the present study between the infants born to the painters and those born to the electronics workers should be interpreted with caution. The number of children was small, and so were the differences in birth weight and birth length. The results agree however, with other findings, ${ }^{8-15}$ suggesting that occupational exposure of the father to organic solvents can affect the outcome of pregnancy. It is not inferred that the small differences in weight 
and length recorded in the present study are an indication of an abnormal development of the child. The difference is possibly due to a slightly shorter duration of a normal pregnancy, although the recorded data give no clear evidence of an increased rate of prematurity. From their data, Daniell and Vaughan ${ }^{14}$ concluded that the excess risk of low birth weight among children born to solvent exposed fathers is due to growth retardation rather than prematurity. Two observations from the present study support that. Firstly, the mean weight and length of the infants of the spray painters were still smaller (although $p>0.05$ ) than the corresponding data for the infants of the electronics workers if only near normal term infants were analysed. Secondly, the mean length $(p<0.05)$ and also weight (although $p>0.05$ ) of the children of spray painters were smaller than those of the children of electronics workers after an attempt to correct for the tendency among children of spray painters to be born slightly earlier than the children of electronics workers.

The cause of the lower weight and length of the children of the spray painters in the present study is unknown. Hypothetically, the mothers could have been indirectly exposed to solvents via the fathers. Alternatively, exposure to solvents by an unknown mechanism could directly affect the reproductive function of the father.

We gratefully acknowledge the competent assistance of Ms Gun Carlsson, and Ms Ingeborg Lomaeus in the collection of the data, and Ms Maud Hagman and $\mathrm{Mr}$ Tomas Persson in the statistical treatment of these data. This study was supported by the Swedish Medical Research Council grant number 3681.

1 Funes-Cravioto F, Zapata-Gayon C; Kolmodin-Hedman B, Lambert B, Lindsten J, Norberg E, et al. Chromosome aberrations and sister-chromatid exchange in workers in chemical laboratories and a rotoprinting factory and in children of women laboratory workers. Lancet 1977;ii:322-5.

2 Holmberg PC. Central-nervous-system defects in children born to mothers exposed to organic solvents during pregnancy. Lancet 1979;ii:177-9.

3 Holmberg PC, Hernberg S, Kurppa K, Rantala K, Riala R. Oral clefts and organic solvent exposure during pregnancy. Int Arch Occup Environ Health 1982;50:371-6.

4 Hemminki K, Axelson O, Niemi M-L, Ahlborg G. Assessment of methods and results of reproductive occupational epidemiology: Spontaneous abortions and malformations in the offspring of working women. Am J Ind Med 1983;4: 293-307.

5 Hemminki K, Vineis P. Extrapolation of the evidence on teratogenecity of chemicals between humans and experimental animals: chemicals other than drugs. Teratogen Carcinog Mutagen 1985;5:251-318.

6 Pearn JA. Teratogens and the male. An analysis with special reference to herbicide exposure. Med J Aust 1983;2:16-20.

7 Brown NA. Are offspring at risk from their father's exposure to toxins? Nature 1985;316:110.

8 Bjerrehus T, Detlefsen G. Infertilitet hos danske malere udsat for organiske oplosningsmidler. (Infertility in Danish painters exposed to organic solvents.) Ugeskr Laeger 1986;148:1105-6. (In Danish with English summary).

9 Erickson JD, Cochran WM, Anderson CE. Parental occupation and birth defects: a preliminary report. Contrib Epidemiol Biostat 1979;1:107-17.

10 Olsen J. Risk of exposure to teratogens amongst laboratory staff and painters. Dan Med Bull 1983;30:24-8.

11 Peters JM, Preston-Martin S, Yu MC. Brain tumours in children and occupational exposure of parents. Science 1981;213:235-7.

12 Mikkelsen S. Reproduction and male solvent exposure: A study of children of painters. Abstracts third conference on epidemiology in occupational health, Singapore 28-30 September 1983. Scand $J$ Work Environ Health 1984;10:133.

13 Mikkelsen S, Haxholdt H, Jorgensen M. Bern av malere. En undersogelse av risikoen for skadevirkninger pả børnene, når faderen udsaettes for opløsningsmidler $i$ arbejdet. Slutrapport projekt 1979-36. Arbejdsmiljøfondet, København 1983. (An investigation of the risk for adverse outcomes in the children, when the father is occupationally exposed to organic solvents). Copenhagen: Arbejdsmiljøfondet, 1983. (In Danish with English summary.)

14 Daniell WE, Vaughan TL. Paternal employment in solvent related occupations and adverse pregnancy outcomes. Br J Ind Med 1988;45:193-7.

15 Taskinen H, Anttila A, Lindbohm M-L, Sallmén M, Hemminki $K$. Spontaneous abortions and congenital malformations among the wives of men occupationally exposed to organic solvents. Scand J Work Environ Health 1989;15:345-52.

16 Elofsson S-A, Gamberale F, Hindmarsh T, Iregren A, Isaksson A, Johnsson I, et al. Exposure to organic solvents. A crosssectional epidemiologic investigation on occupationally exposed car and industrial spray painters with special reference to the nervous system. Scand JWork Environ Health 1980;6:239-73.

Accepted 19 August 1991 